\title{
Are trained teacher-librarians making a difference for school libraries in South Africa?
}

\author{
Sandy Zinn \\ Lecturer \\ University of the Western Cape \\ South Africa
}

\begin{abstract}
The purpose of this research was to trace former UWC students who trained as teacher-librarians between 1976 and 2000 in order to ascertain how influential they have been in their school's library and reading programmes. The study revealed that although most respondents had progressed in rank at schools, their role in the library programme was minimal. Most schools had either no library or defunct library programmes. Respondents were much more active in formal reading programmes. Computers with Internet access were evident at most schools but teachers were using computers mostly for managing marks and setting exams.
\end{abstract}

\section{Background to the study}

From 1976 until about 2000, school librarian training, particularly for House of Representative (Coloured) schools, took place at the University of the Western Cape (UWC) in the Library and Information Science (LIS) Department. From 1997 it became increasingly difficult for teachers to take time-off to study fulltime. By 2000, as specialist posts were abolished at schools, the training of school librarians trickled to zero. At about the same time, a total restructuring in the categorization of teachers meant that improved qualifications were no longer a guarantee for salaried promotion.

Whilst changes in curriculum were being implemented, school libraries, where they existed before, were closing down as personnel were being cut. Yet, the changes in education now focused on resource-based learning, discovery learning, learner-centred approaches - all changes demanding a good school library programme.

In 2003 the UWC Department of LIS responded by offering short, intensive courses in school librarianship during school holidays. The bases for the department's decision to teach the short courses were:

1. the school curriculum is resource-based and schools need functioning school libraries to enable Outcomes-based Education to succeed;

2. there was a small, but growing push from the schools ( but not the national department of education) for teacher-librarian training;

3. teachers were still having difficulty getting time off to study fulltime;

4. the time seemed to be right for focusing on school libraries as other infrastructure fundamentals like water, sanitation, and electricity had been improving in schools; and

5. very few universities in South Africa train teacher-librarians (only 3 in the country). 
The UWC LIS Department's case was strengthened by:

1. Kader Asmal's (then head of national education) Seventh report on the Provinces to the President in which he reported a total of 21912 schools without libraries (Ntshwanti-Khumalo \& Bot, 2004, p.28);

2. Then deputy education Minister, Mosibudi Mangena's support for a school library policy (Matomela, 2003).

3. The National Report on Systemic Evaluation (Pretoria News 17/6/03) which drew a high correlation between school library resources and learners' scores for literacy and numeracy.

In March 2005 the new Minister of Education, Naledi Pandor, requested that the first-ever National Policy Framework for School library Standards drafted in 1997 be re-considered. A new National School Library Policy document is presently being deliberated at national level amongst education heads of provinces.

\section{Motivation for the study}

Schools have begun to both re-establish old and establish new school libraries and they are looking for qualified librarians. In addition, the probability, that national policy for school library norms and standards will be passed this year, is high given the drive by the Minister of education herself. The UWC LIS department has not kept track of its qualified teacherlibrarians. Now would be an opportune time to undertake a study to locate teacher-librarians trained by UWC between 1976 and 2000. The reasons for tracing these teacher-librarians would be to ascertain how influential they have been in:

1. keeping a school library programme running in the face of tremendous obstacles;

2. the school's reading programme;

3. merging the school's information and communication technology (ICT) programme with the school library programme

It was hoped that the study would also inform the UWC LIS department and the research community about the preparedness of trained teacher-librarians to take a leadership role in their schools; the extent to which individuals have continued to make a contribution to the school library or reading programme; and whether they have made the link between ICT and libraries.

\section{Review of the literature}

The present educational context in South Africa cannot be separated from its historical past. The legacy of Apartheid continues to haunt the new educational offerings. The literature emerging on education in South Africa confronts two burning issues: quality and socio-economic class (Bot, 2005; Chisholm, 2004 \& 2005; Fiske \& Ladd, 2004). The new outcomes-based curriculum has been implemented best in middle class schools - mostly previously White schools - where parents pay fees to hold on to their 'privilege and edge over poor schools by employing additional teachers and improved resources to ensure better quality teaching' (Chisholm, 2005, p. 211). In these schools class has replaced race as a condition of entry. For previously Coloured and Black schools in working class areas, equity in education has remained elusive in South Africa (Fiske \& Ladd, 2004, p. 234). It is these latter schools that perform abysmally on both local and international literacy and numeracy tests. 
Despite the series of tests conducted over the years that proved low reading levels amongst Grade 3 learners (In 2004, only 39.5\% of Western Cape Grade 3 learners could read at the appropriate level), education department solutions omitted the specific role of a school library (Smith, 2005, p.10; WCED, 2002, p.2). Jenny Karlsson (2005), in her keynote address at the E-education Conference in Bloemfontein, referred to this oversight as the education department's 'blind spot'. In fact, since 2001 there has been a void at national education level, with nobody taking the lead for the school library fraternity.

In 2005 the Minister of Education, Naledi Pandor, resurrected the 1997 National Policy Framework for School Library Standards and publicly made the connection between the development of school libraries and improved literacy levels (Mantu, 2005). The policy and its implementation still have a long road to travel. The number of schools without libraries in 2002 averaged 78\%! In the Western Cape where the research took place, 46\% of schools have no libraries (Bot, 2005, p. 6). The Western Cape Statistic is not to be trusted as often principals assume a library is a 'place', a room, with a few dusty, old books. Quite often there is absolutely no school library activity.

What then seems to be the tipping point? Probably a combination of factors such as the leadership of Minister Pandor, basic infrastructural elements like electricity, enough classrooms, sanitation and access to water and feeding schemes in place, and above all the recognition that successful implementation of the new curriculum cannot be achieved without a good school library programme.

Two recent research studies conducted by the Western Cape Education Department (2005 \& 2006) emphasize school libraries. The first was a systemic evaluation of Grade 6 learners in which access to information was seen as a significant factor associated with learner achievement (WCED, 2005, p.101-102). The recommendations of the Grade 6 systemic study prioritise school libraries, trained school library personnel, well-stocked libraries and pre-service educator training in school library management (p. 118). This is a groundbreaking finding for South Africa and paves the way for more evidence-based research such as the Ohio Study (Todd, et al, 2004), the Lance studies (2000) and more recently the Ontario Library Association's (2006) study of the strong correlation between school libraries and student achievement. The second WCED study entitled a human capital development strategy for the Western Cape (2006, p.41) goes a step further than planning 'resource centres and libraries' at each school to include ICT literacy as well.

In 2001 the Western Cape Provincial Government identified the importance of ICTs in education and embarked on a roll-out of computers to all schools in the province. The first level of commitment was to streamline communication with all schools through an efficient email system. To this end all (roughly 1500 ) schools were to receive a computer with connectivity for administrative purposes. The second roll-out was the Khanya-ICT project which focussed on maths and science teaching in identified high schools. This project saw the establishment of computer labs with networked computers and Internet access. The third phase targeted primary schools. The WCED is regarded as a leader in educational ICT in this country. Yet, questions remain about the effective use of computers in schools.

Wilson-Strydom, et al (2005, p. 73-74) use the UNESCO four-stage continuum of ICT integration as a measure of ICT curriculum and teacher development as they feel it is more closely associated with ICT use than mere ICT adoption. Stage one, the 'emerging' stage, is associated with schools that have just started buying computer equipment. Teachers 
are at the exploratory ICT stage and are engaged in traditional transmission teaching methods. Stage two, the 'applying' stage, teachers and school administrators use ICT for school management tasks. The pedagogy is still teacher dominant. Stage three, the 'infusing' stage, is where ICT begins to be integrated across the curriculum. At this stage ICT changes teachers' 'personal productivity and professional practice'. The final stage, the 'transforming' stage, ICT alters schools fundamentally. ICT is seamlessly incorporated into all ways of teaching and learning.

The Wilson-Strydom, et al (2005, p. 79) study, which evaluates the Intel® Teach to the Future programme in South Africa, confirms aspects of a previous study conducted by Lundall \& Howell in 2000 (as quoted in Howie, et al, 2005, p. 109) that computers in schools are still mainly used for administration purposes, the UNESCO 'applying' stage. Ironically, these studies identify most teachers at the 'emerging' stage. The lack of computer literacy amongst South African educators is the result of deficiencies in pre-service teacher training, the cost of in-service training, time-constraints and too few computers to go around. In the survey findings, teachers' ICT skills and knowledge strongly reflect the literature.

\section{Research Questions \& Methodology}

\section{Methodology}

The list of contact details of all ex-Diploma in School Librarianship (DSL) students was generated by the University of the Western Cape's Records Department. One hundred and forty eight (148) ex-DSL students were mailed a questionnaire. Those assumed retired (60 years of age or older) of which there were about 50 people and those who had emigrated were disregarded as this study targeted those deemed still active in service. Responses were hoped for by late January 2006.

\section{Questionnaire}

The questions posed related to:

- the personal position/rank of the teacher in the school;

- any higher qualification attained since completing the Diploma in School librarianship;

- the mobility of teachers within schools and into schools previously socially exclusive;

- the role of the school librarian in the school's literacy programme;

- the multilingual nature of the school;

- school library facilities and programme activity;

- the influence of the school librarian in school library orientated matters;

- the teaching of information literacy skills as part of the library programme;

- access to ICT and its role in the curriculum;

- gaps in the knowledge and skills of previously-trained school librarians

\section{Research Findings \& Discussion}

The low number of responses was disappointing. Thirty surveys were returned "gone away no address left", two people were deceased, and 2 had taken early retirement. Only 26 
surveys were returned completed - or $22.8 \%$. A limiting factor which may account for the poor response rate may have been that the survey was in English whilst many respondents' home language was Afrikaans. The researcher hopes to build on the present research data by posting an Afrikaans version of the survey. An alternative but time-consuming and costly method of data collection in South Africa would be a telephone survey, a route the researcher may have to follow. Another mitigating factor for the poor response rate is the lack of a habit of using forwarding addresses in the postal service. Hence, many letters are simply binned.

Of the 26 respondents who completed the questionnaire, 15 were male and 11 were female. By far the majority of respondents were in their middle years, aged 41-50.

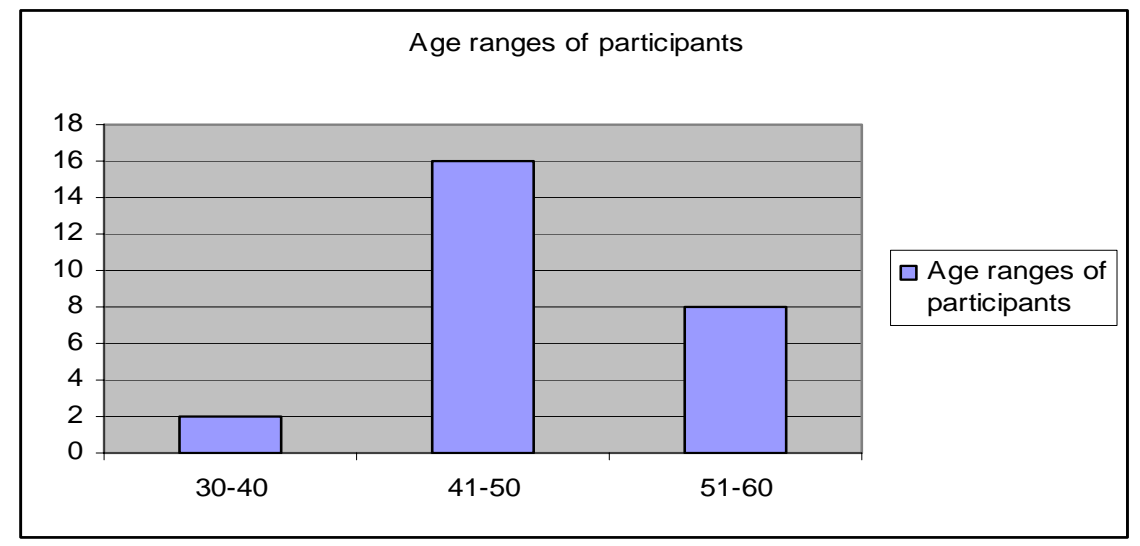

Figure 1. Participants' age range was concentrated in the $41-50$ years

\section{Employment Patterns}

Respondents out of a school. A significant 31\% of the total are no longer employed in a school. The range of other employment opportunities is quite wide: from the private sector to local government to an NGO. At least 2 indicated explicit use of their librarian training. The case of the supply teacher in the UK is interesting as many past specialist teachers, such as music teachers in this case, are finding contract employment in the UK. Many recently qualified teachers are also choosing to work abroad as negative perceptions about South African schooling influence choices.

Respondents in a school. Eighteen (18) respondents still teach fulltime in a school. Nine respondents teach in a primary school (Grades 0-7), three in an Intermediate school (Grades 0-8) and six in a high school (Grades 8-12). Sixteen respondents teach in a school previously designated for Coloureds, one teaches in a Black school and one in a US school. The majority has remained in the racially designated schools for Coloureds.

\section{Qualifications and rank}

An almost equal number of respondents remained at the DSL level as went on to improve their qualifications. Most participants who entered the DSL, only had a 3 year postMatric Teacher Training qualification from a teacher training college. The DSL was often the stepping stone to furthering their education. Six respondents have since completed their bachelor's degree, three an honour's degree and one a Masters degree. The remaining three have completed a $4^{\text {th }}$ year of teacher training. See figure 2 below. 


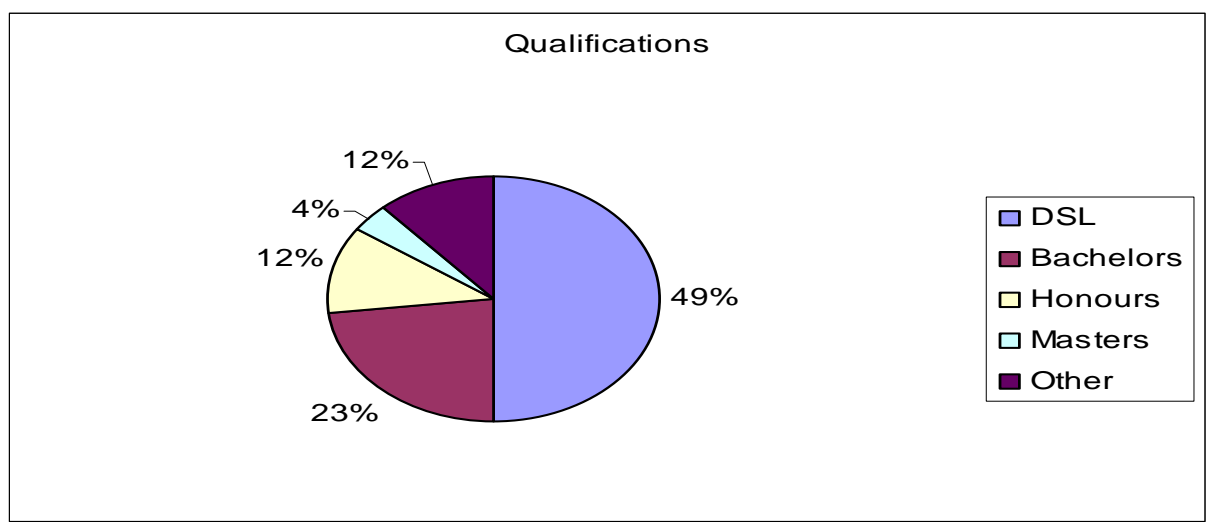

Figure 2: More than half the educators have improved their qualifications

A clear majority of respondents have taught more than 16 years, some almost 35 years. Of the respondents still at a school fulltime, a significant 8 (all male) have become principals, 3 deputy principals and 3 heads of phases at school (see figure 3). Only 3 remained at the designation at which they started. The interesting exception is the case of the one respondent who now works as a school media centre specialist in the US. Many a South African teacher has been contracted to work in the US for 3-year periods. The teachers are usually well-qualified and go to gain experience and to travel.

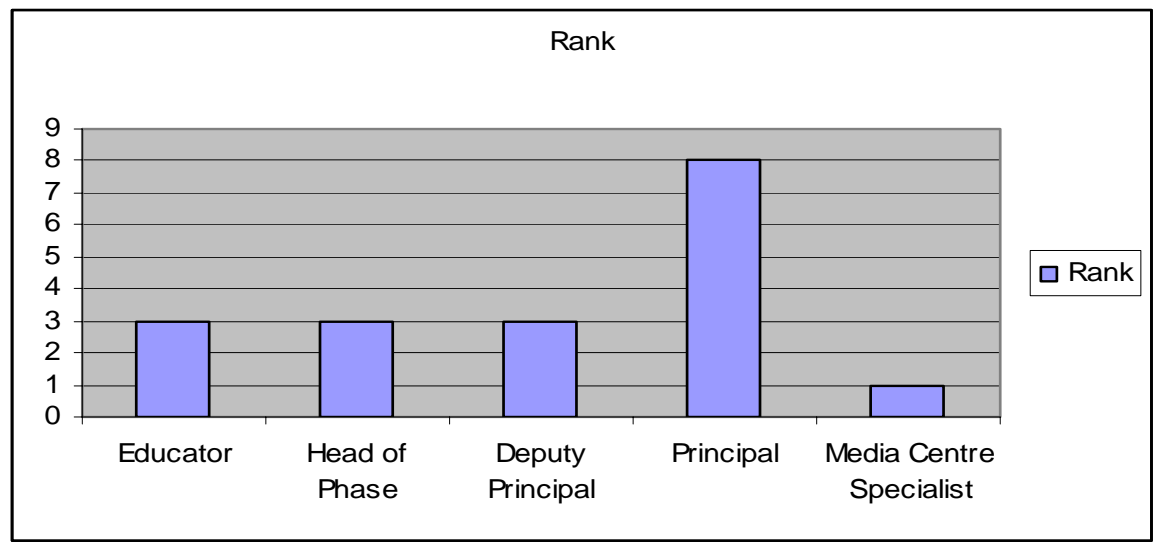

Figure 3: Most of the teachers have improved their rank in the school

\section{Multilingualism \& Literacy}

Home language versus language of instruction. In South Africa an ongoing debate rages about mother tongue instruction. Both the literature and educational language policies emphasize the importance of learning in the first (home) language at least for the first 4 years of schooling when crucial cognitive learning takes place. Unfortunately, parents view English as the language of upward mobility. Parents' impressions are shaped by the media, leaders, and successful entrepreneurs all of whom use English to communicate. One school in the survey has Xhosa speaking learners whose parents insist that English be the language of learning and teaching (LOLT)! Comparing figures 4 and 5, while Afrikaans is the predominant home language, English as a LOLT is cited more often by respondents. One negative outcome of a preference for English is the low level of reading. The WCED (2006, p. 32) study revealed that in 2003, 82\% of Grade 6 learners were reading at the Grade 3 level. 


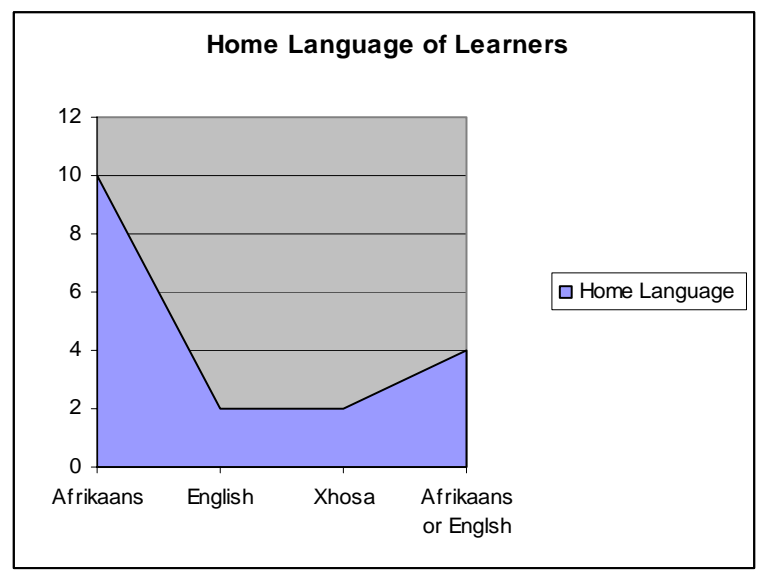

Figure 4: Predominant home language is Afrikaans

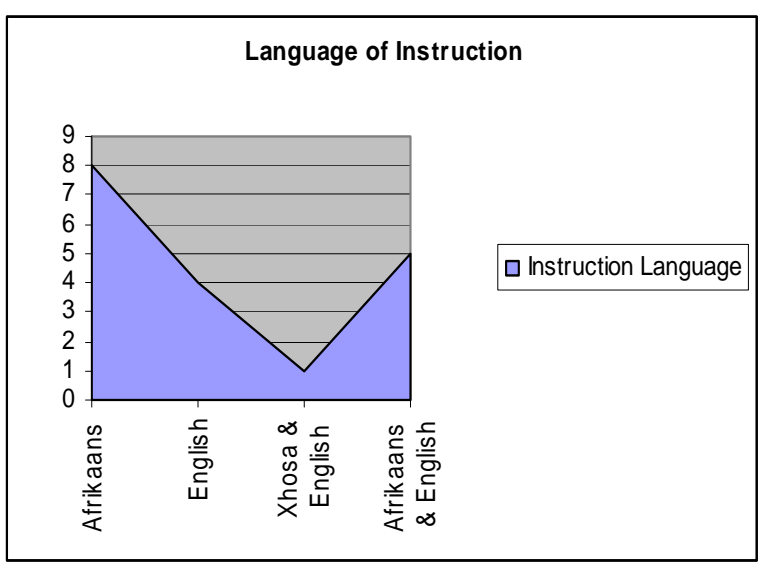

Figure 5: More schools opt for English as a LOLT than any other language

Literacy Programme. After the first research revealed the low literacy and mathematical levels in South African schools, the WCED instituted a 30 minutes a day reading programme in all schools up till Grade 9 . This was a formally managed programme with the intention of stimulating reading for enjoyment. The success of such a programme would depend on access to reading material.

The survey asked whether or not schools instituted this formal reading period. Thirteen schools indicated yes and 5 indicated no. Of the 5 schools that indicated in the negative, 3 are primary schools where one would expect the development of reading to play a sizeable part in the curriculum.

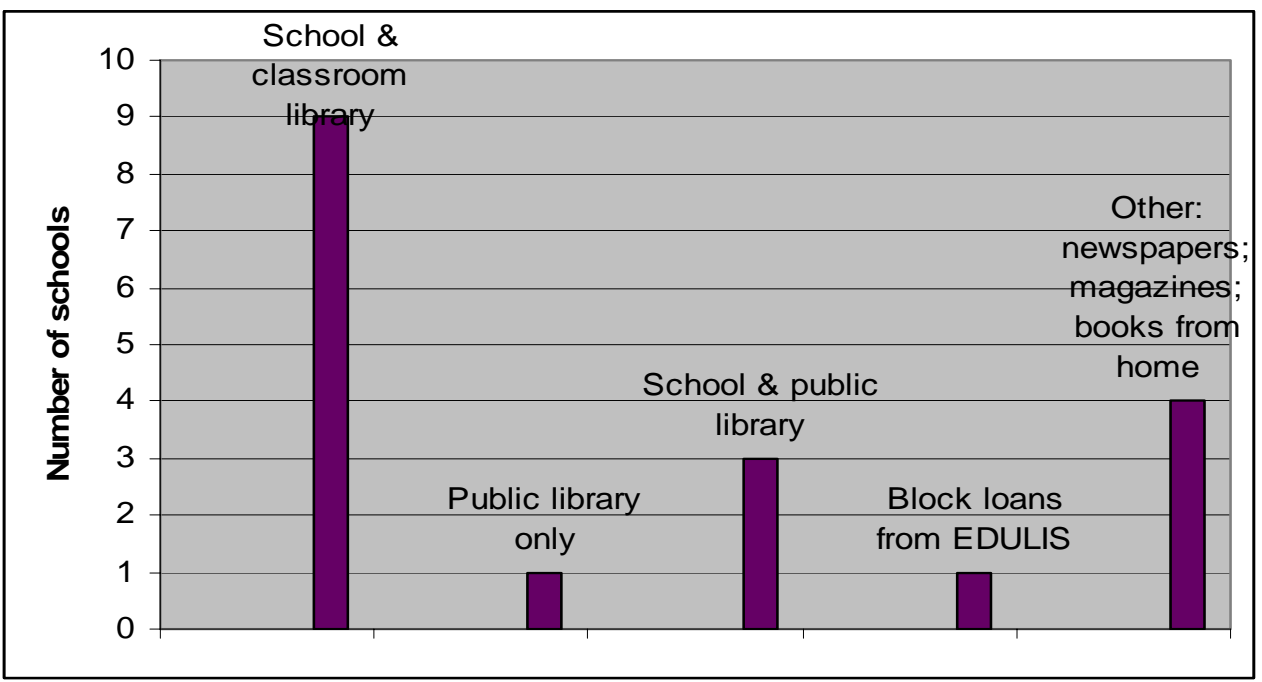

Figure 6: Sources for reading programme

Inconsistencies started to emerge when asked about sources for reading material and the size of the school library. No school library held more than 2000 books. Most schools ranged in size from 750-1500 learners. The stock of the school library would therefore be quite inadequate for a successful school reading programme.

While 11 schools indicated that they had a library, 7 claimed that they did not. Only 5 respondents completed the library stock section despite asking for approximations only. 
Respondents pointed out that stock was replenished mostly from donations. Datedness seemed to be an apt adjective to describe the stock. Most indicated their best set of encyclopaedias was more than 20 years old. The WCED must have been cognisant of the low status of the school library because Circular Number 110 of 2002 suggested several ways of accessing reading material which omitted the school library. Instead they suggested appealing for donations, loaning blocks of books from the Education Library \& Information Service (EDULIS), visiting the local library, tape-recorded books and newspaper subscriptions $(\mathrm{p} 2,2.5 .5)$.

\section{Respondents' role in the reading \& library programmes}

Library programme. A disappointing 4 of the 11 respondents with libraries signify they play no role at all. Four are in administrative positions as principals or deputy principals and act as overseers of the library programme. Two (2) respondents have recently organised a library venue, have no active programme now but will have one in the future. One (1) did not specify a role. Unlike the Radebe (1997) study set in KwaZulu Natal , most of the respondents in this study were not ordinary rank and file teachers but senior administrators. Fifty eight percent (58\%) of the teachers in the Radebe study had no libraries at their school supplying one of the reasons as lack of support from school administrators.

Reading programme. Respondents were much more active in the reading programme than the library programme. Of the 13 schools with a reading programme, 4 who are school administrators control or oversee the reading programme in the entire school. Five respondents are only involved with their own class's reading, while one is in charge of a phase (one phase equals 3 grade levels) and one coordinates a language in the school. Two played no role in the reading programme.

\section{The school library programme}

The number of schools with a library dropped in the Western Cape after 1994, the year of South Africa's first democratic election. As specialist posts in schools were cut, schools either lost their teacher-librarians or absorbed them into the classroom. With nobody to manage and organise the library, books were boxed and many a library either used as a classroom or turned into a computer lab. It was no surprise, therefore, when survey statistics returned mirrored these scenarios. There was no real school library programme to talk of as respondents ticked school library activity as mostly a non-event. On the other hand, evidence from the surveys showed a growing awareness for computers.

\section{Information and communication technologies}

Seventeen (17) schools had access to computers and 13 had Internet access. All the high schools had at least one computer lab and only one high school had no access to the Internet. Internet access was for both teachers and learners at high schools. Most high schools still placed a premium on computer literacy classes and were thus not using computers to generate new knowledge or truly integrate computers across the curriculum. Only school C, the US school, is convincing (see table 1).

\begin{tabular}{|c|c|c|c|c|c|c|}
\hline $\begin{array}{c}\text { High } \\
\text { School }\end{array}$ & $\begin{array}{c}\text { Total number of } \\
\text { computers in the } \\
\text { school }\end{array}$ & $\begin{array}{c}\text { The school } \\
\text { has a } \\
\text { library }\end{array}$ & $\begin{array}{c}\text { Computer } \\
\text { literacy } \\
\text { classes }\end{array}$ & $\begin{array}{c}\text { Internet } \\
\text { Access }\end{array}$ & $\begin{array}{c}\text { Computer } \\
\text { integration with } \\
\text { curriculum }\end{array}$ & $\begin{array}{c}\text { Email } \\
\text { collaboration } \\
\text { projects }\end{array}$ \\
\hline A & 33 & yes & yes & no & every day & no \\
\hline
\end{tabular}




\begin{tabular}{|c|c|c|c|c|c|c|}
\hline B & 80 & yes & yes & yes & not yet & no \\
\hline C & 128 & yes & no & yes & every day & yes \\
\hline D & 34 & no & yes & yes & Once p/month & yes \\
\hline E & 29 & no & no & yes & Once p/week & yes \\
\hline F & 35 & no & yes & yes & every day & no \\
\hline
\end{tabular}

Table 1: ICT access and usage in respondents' high schools

Of the primary and intermediate schools at least three did not have a computer lab. Computer literacy classes were taught at only 4 of these 11 schools. Very often schools cannot afford an ICT teacher. Eight (8) schools had Internet access but only two (2) provided access for both teachers and learners. Again, this is a cost factor as Internet access in South Africa is prohibitive. The researcher regards with serious doubt whether the concept computer integration across the curriculum was understood. Intermediate School B has definitely misunderstood the term. It should also be noted that teachers provided more accurate statistics on the ICT section of the survey than the school library stock section. See tables 2 \& 3 below.

\begin{tabular}{|c|c|c|c|c|c|c|}
\hline $\begin{array}{c}\text { Primary } \\
\text { school }\end{array}$ & $\begin{array}{l}\text { Total number } \\
\text { of computers } \\
\text { in the school }\end{array}$ & $\begin{array}{c}\text { The school } \\
\text { has a } \\
\text { library }\end{array}$ & $\begin{array}{c}\text { Computer } \\
\text { literacy } \\
\text { classes }\end{array}$ & $\begin{array}{l}\text { Internet } \\
\text { access }\end{array}$ & $\begin{array}{l}\text { Computer } \\
\text { integration with } \\
\text { curriculum }\end{array}$ & $\begin{array}{c}\text { Email } \\
\text { collaboration } \\
\text { projects }\end{array}$ \\
\hline$A$ & 6 & yes & $\overline{\text { no }}$ & $\begin{array}{c}\text { yes } \\
\text { (teachers) }\end{array}$ & $\overline{\text { no }}$ & no \\
\hline$B$ & 27 & yes & no & no & Once per day & no \\
\hline $\mathrm{C}$ & 13 & no & no & $\begin{array}{c}\text { yes } \\
\text { (teachers) }\end{array}$ & $\begin{array}{c}\text { Once every } 2 \\
\text { weeks }\end{array}$ & no \\
\hline $\mathrm{D}$ & 26 & yes & yes & $\begin{array}{c}\text { Yes } \\
\text { (learners \& } \\
\text { teachers) }\end{array}$ & $\begin{array}{c}\text { Once every } 2 \\
\text { weeks }\end{array}$ & no \\
\hline$E$ & 2 & yes & no & $\begin{array}{c}\text { Yes } \\
\text { (teachers) }\end{array}$ & no & no \\
\hline$F$ & 40 & yes & yes & $\begin{array}{c}\text { Yes } \\
\text { (teachers) }\end{array}$ & no & no \\
\hline$G$ & 24 & yes & yes & $\begin{array}{c}\text { Yes } \\
\text { (learners \& } \\
\text { teachers) }\end{array}$ & no & no \\
\hline $\mathrm{H}$ & 40 & yes & yes & $\begin{array}{c}\text { Yes } \\
\text { (teachers) }\end{array}$ & no & no \\
\hline
\end{tabular}

Table 2: ICT access and integration in respondents' primary schools

\begin{tabular}{|c|c|c|c|l|c|c|}
\hline $\begin{array}{c}\text { Intermediate } \\
\text { School }\end{array}$ & $\begin{array}{c}\text { Total number } \\
\text { of computers } \\
\text { in the school }\end{array}$ & $\begin{array}{c}\text { The school has } \\
\text { a library }\end{array}$ & $\begin{array}{c}\text { Computer } \\
\text { literacy } \\
\text { classes }\end{array}$ & $\begin{array}{l}\text { Internet } \\
\text { Access }\end{array}$ & $\begin{array}{c}\text { Computer } \\
\text { integration with } \\
\text { curriculum }\end{array}$ & $\begin{array}{c}\text { Email } \\
\text { collaboration } \\
\text { projects }\end{array}$ \\
\hline A & 26 & no & no & no & $\begin{array}{c}\text { Once every } 2 \\
\text { weeks }\end{array}$ & No \\
\hline B & 3 & no & no & no & $\begin{array}{c}\text { Once per } \\
\text { month }\end{array}$ & No \\
\hline C & 12 & no & no & $\begin{array}{l}\text { Yes } \\
\text { (teachers) }\end{array}$ & When needed & no \\
\hline
\end{tabular}

Table 3: ICT access and integration in respondents' intermediate schools

\section{Personal use of computers}

Figure 7 demonstrates the uses to which teachers put computers. Managing marks and drawing up exam papers, both administrative tasks, ranked highest. This evidence confirms 
research undertaken by Wilson-Strydom, et al (2005) and Lundall \& Howell (as quoted in Howie, et al, 2005) that teachers are mainly using computers for administrative tasks. It is encouraging to see that more teachers are using email although they have not extended email to collaborative projects in the curriculum. Too few of them (5/6) are searching for information on the Internet for either lessons or personal use, despite access by 13 respondents to the Internet. This is again consistent with the Wilson-Strydom, et al (2005) research.

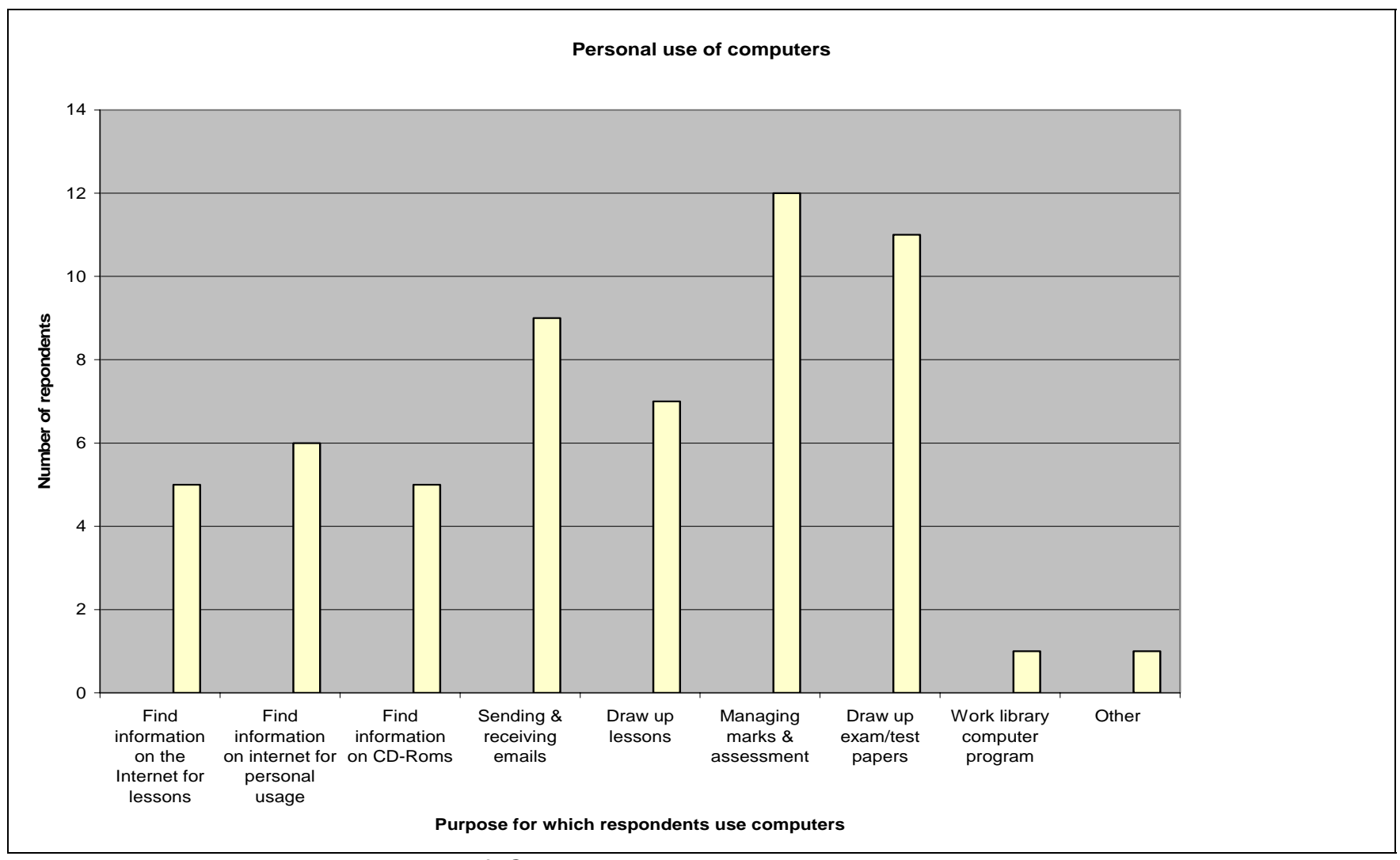

Figure 7: Respondents' personal use of ICTs

\section{Conclusion}

This research revealed that UWC trained teacher-librarians have a high-ranking role in schools but that their influence in the school library has been minimal. They play a stronger role in the school reading and ICT programme. Reasons for these results are stipulated below.

- Many teachers completed the DSL with the express purpose of monetary gain and not to develop a school library;

- The teachers of the DSL programme were ambitious to start with and rose naturally in the ranks at school;

- The lack of a school library policy at national and provincial level provided no impetus for developing a school library;

- The changes in funding formulae for library material meant that the latter was no longer ring-fenced;

- Poorer schools could not afford to employ extra teachers and in prioritising cut teacher-librarians;

- There is a stronger campaign in education around reading than libraries; 
- ICT skills are seen as important in our technologically-driven working environments. Driving an ICT programme is therefore more attractive than focussing on libraries (meaning focussing on books).

- The low level of ICT integration and the lack of library programmes meant that a convergence of the two was not possible in the near future.

\section{References}

Bot, M. (2005). School education in South Africa: tracking change over ten years. Edusource Data News 48, 110

Chisholm, L. (2005). The state of South Africa's schools. In Daniel, J., Southall, R \& Lutchman, J. (Eds.), State of the Nation: South Africa 2004-2005 (pp.210-226).Cape Town: HSRC Press. Retrieved February 23, 2006, from the World Wide Web: http://www.hsrcpress.ac.za

Chisholm, L. (2004). Introduction. In Chisholm, L. (Ed.) Changing class: education and social change in postapartheid South Africa (pp. 1-28). London: Zed Books

Department of Education (2005). Draft: National School Library Policy. Pretoria: Department of Education.

Fiske, E.B. \& Ladd, H.F. (2004). Elusive equity. Washington, D.C.: Brookings Institution Press.

Howie, S.J., Muller, A. \& Paterson, A. (2005). Information and communication technologies in South African secondary schools. Cape Town: HSRC Press. Retrieved February 22, 2006, from the World Wide Web: http://www.hsrcpress.ac.za

Karlsson, J. (2005). The transformation of teaching and learning in the e-education age. Keynote address presented at the e-Education and ELITS Conference held in Bloemfontein from March 21-23, 2005.

Lance, K. C., Rodney, M.J. \& Hamilton-Pennell, C. (2000). How school librarians help kids achieve standards: the second Colorado study. Spring, TX: Hi Willow Research and Publishing

Mantu, R. (2005). Write South African stories to spur youth to read. BuaNews, April 24, 2005. Retrieved December 19, 2005 from the World Wide Web: http://buanews.gov.gov.za/

Matomela, Nombini (2003). Education department formulates policy on school libraries. BuaNews, 7 July 2003. Retrieved August 27, 2004 from the World Wide Web: http://www.buanews.gov.za/view.php?ID=03070714461001\&coll=buanew03

Ntshwanti-Khumalo, T.S. \& Bot, M. (2004). Provincialisation of education: a review (January 2003-December 2003). Edusource Data News 44, 8-38.

People for education. (2006). School libraries and student achievement in Ontario. Toronto: Ontario Library Association. Retrieved April 13, 2006 from the World Wide Web: http://www.peopleforeducation.com/reports/library/OLAstudy.pdf

Radebe, T. (1997). Experiences of teacher librarians in the workplace after completion of the school librarianship programme. South African Journal of Library and Information Science, 65(4), 218-26.

Smith, T. (2005). The writing isn’t on the wall for nine-year old pupils. Cape Argus, June 7, 2005, p. 10

Todd, R. J., Kuhlthau, C. C. \& OELMA (2004). Student learning through Ohio school libraries: the Ohio research study. Columbus, OH: Ohio Educational Library Media Association. Retrieved June 6, 2004 from the World Wide Web: http://www.oelma.org/studntlearning.htm

Western Cape Education Department (2005). Grade 6 systemic evaluation: Western Cape Province. Cape Town: WCED. 
Western Cape Education Department. (2006). A human capital development strategy for the Western Cape: a focus on youth. Cape Town: WCED. Retrieved March 23, 2006, from the World Wide Web: http://wced.wcape.gov.za

Western Cape Education Department (2002). Literacy development in schools. Circular no. 0110/2002. Cape Town: WCED

Wilson-Strydom, M., Thomson, J. \& Hodgkinson-Williams, C. (2005). Understanding ICT integration in South African classrooms. Perspectives in Education, 23(4), 71-85.

\section{Author Note:}

Sandy Zinn is a lecturer in the Department of Library \& Information Science, University of the Western Cape, South Africa. Her career has taken her from public librarian, to school librarian, to curriculum advisor: information literacy skills and finally to university lecturer. Sandy co-ordinates and teaches courses in the programmes Short Courses in Teacher-Librarianship and the Advanced Certificate in Education: School Librarianship. Her research interests are information literacy and ICT literacy at the school level, teacher-librarian education and e-learning. She has published several papers, edited conference proceedings and spoken at local and international conferences. 
Reproduced with permission of the copyright owner. Further reproduction prohibited without permission. 